\title{
HILDENBRANDIA RIVULARIS (RHODOPHYTA) IN CENTRAL POLAND
}

\author{
JOANNA ŻELAZNA-WIECZOREK ${ }^{1}$, MACIEJ ZIUŁKIEWICZ ${ }^{2}$ \\ ${ }^{1}$ Department of Algology and Mycology, University of Łódź \\ Banacha 12/16, 90-237 Łódź, Poland \\ e-mail: joannazelaznawieczorek@yahoo.co.uk \\ 2 Department of Geology, Univeristy of Łódź \\ Narutowicza 88, 90-139 Łódź, Poland
}

(Received: September 12, 2006. Accepted: November 15, 2006)

\begin{abstract}
Freshwater red algae Hildenbrandia rivularis has been noted for the first time in central Poland near the Lodz agglomeration. Until now, this alga was recorded only in mountain and Polish Lowland areas. The wide range of habitat conditions influencing the occurrence for this protected species has been determined in the spring niche. The possible threat to habitat where $H$. rivularis occurs, is connected with construction and exploitation of the A2 highway.
\end{abstract}

KEY WORDS: Rhodophyta, spring, hydrochemical conditions.

\section{INTRODUCTION}

Hildenbrandia rivularis (Liebm.) I. Ag. 1851 belong to phyllum Rhodophyta, class Florideophyceae. It represents of red algae occurring in fresh inland waters. This alga is situated on the Red List of threatened algae in Poland (Siemińska 1992), as a vulnerable plant (V), the alga is known from seldom stands with very small quantities, and is under species low protection in Poland.

The first occurrence of this alga in Poland has been noted in the first half of 20th century and included mountain and submountain areas of the Karpaty and Sudety mountains, Baltic Pomeranian and Wielkopolska (Krawiec 1935, Starmach 1951). In the second half of the twentieth century new stands of $H$. rivularis have been recorded in flowing waters from mountainous areas (Starmach 1969a, 1982). Numerous observations concern Pomeranians (Siemińska 1962; Kępczyński 1962, 1972; Żukowski 1963; Lisowski et al. 1971; Chudyba and Polkowski 1977; Markowski 1980) and the northern part of Wielkopolska (Szafrański 1960; Dąbmska 1961; Stępczak and Musiał 1984; Król 1987; Kępczyński and Peplińska 1995). The occurrence of $H$. rivularis has also been noted in standing waters, within the littoral zone of lakes: in Jeziorak Lake (Bohr 1968), Raduńskie Lake and Ostrzyckie Lake (Markowski 1980) and Koleńskie Lake (Gołdyn 1985) (Fig. 1).

Observations of the growth of $H$. rivularis thalii have been presented by Starmach (1969b).

On the basis of habitat conditions occurring in the stands of $H$. rivularis noted up to now in Poland, it can be stated that this alga prefers to flow in shallow waters with fast current, while in standing waters it tends to aggregate in the waving zone, shadow places and stony ground.

The first stand of the $H$. rivularis noted in central Poland was in the spring's niche of the Łódź Hills scarp. This red alga was noted in November 2003 and was observed once per month till June 2005. To determine the habitats' preferences of $H$. rivularis the hydrological and hydrochemical characteristics and measurement of lightens of this stand have been made.

\section{STUDY AREA}

The Łódź Hills is an area with low-yield and sparse springs, similarly to the Polish Lowland (Pazdro and Kozerski 1990). Over the last ten years researches have indicated many new objects in this region (Maksymiuk and Mela 1995; Moniewski 2004). The area of high springs' density is located in the north part of Łódź Hills scarp, where the landscape is changing suddenly from upland in the South to plain lowland in the North. This is an effect of deep erosion produced by rivers, which radially flow to Bzura. Index of springs calculated for this area is equal to values recorded in the Polish lake districts (Moniewski 2004).

All of these springs drain from fluvioglacial, diluvial and eolian Quaternary aquifers (Ziułkiewicz 2005a). The Łódź Hills scarp area is located in the Łódź agglomeration suburban zone. Accelerating urbanization of villages, intensification of agricultural production and development of transport routes (highway A2) have their effects on natural 


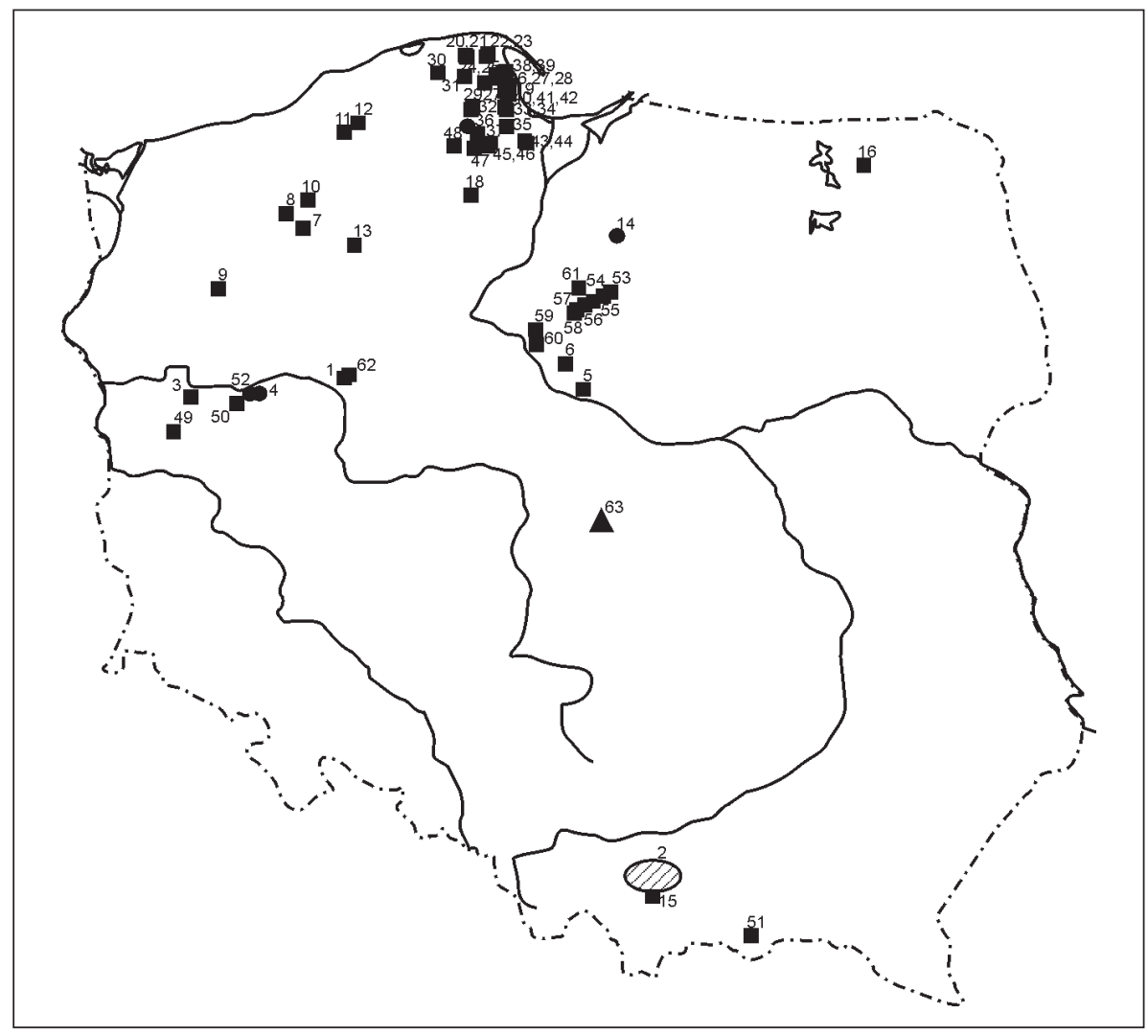

Fig. 1. Occurrence of Hildenbrandia rivularis in Poland. Stands identified between 19351995: 1 - Krawiec (1935); 2 - Starmach (1951); 3 - Szafrański (1960); 4 - Dąmbska (1961); 5, 6 - Kępczyński (1963); 7-9 - Siemińska (1962); 10-13 - Żukowski (1963); 14 - Bohr (1969); 15 - Starmach (1969); 16 Chudyba and Polakowska (1977); 17 - Starmach (1969); 18 - Lisowski, Szafrański and Tobolski (1971); 19-48 - Markowski (1980); 49 - Król (1987); 50 - Stępczak and Musiał (1984); 51 - Starmach (1984); 52 - Gołdyn (1985); 53-61 - Kępczyński (1972); 62 Kępczyński and Peplińska (1995); 63 - new stand near Łódź; - - river; • - lake; $\Delta$ spring.

environmental conditions. These changes have a direct impact on the amount of water resources in this region. The increasing population number raises demands for local water, which results in increasing amount of wastewater disposal to environment. Especially threatened is the shallow groundwater in regions where a water supply system exists but there is no sewage system. In such cases the negative influences are quickly transferred into the springs, which are alimentated by polluted ground waters (Ziułkiewicz 2001, 2003, 2005b; Żelazna-Wieczorek and Ziułkiewicz 2004).

One of the biggest springs in the Łodź Hills scarp is the spring in Ciosny, which supplies the Dzierżązna river (Fig. 2), left tributary of Moszczenica. The mean yield of this spring is $21.3 \mathrm{dm}^{3 *} \mathrm{~s}^{-1}$ (Moniewski 2004). This is the third yield value among all springs in the upper part of the Bzura catchment. The spring area in Ciosny has a clearly elongated shape, characteristic for the large form of springs in the Łódź Hills scarp (Fig. 3). Individual water outflows are located at the bottom of the slope in this area. The spring in Ciosny is located on the outskirts of Grotniki-Lućmierz sandr and contributes to flooding-lake and fluvioglacial sandy sediments.

Yield and abundance characteristic for these springs, was calculated during a two-year investigation (2003-2004). This has demonstrated that large groundwater resources in sandr sediments are reached and their exchange rate is rapid - less than one per year. It was confirmed by a value of hydrochemical indexes, illustrating the important role of conservative elements: $\mathrm{Cl}^{-}$and $\mathrm{Na}^{+}$(Ziułkiewicz 2005a).

Fig. 2. Course of the highway A2 section between Emilia and Stryków and localization of the Ciosny spring: $\mathrm{a}$ - topographic water divide; $\mathrm{b}$ hydroizohypses (thanks to Hydrology and Water Management Department of the University of Łódź); c - course of the highway A2; d - storage-infiltration reservoir; e-spring.

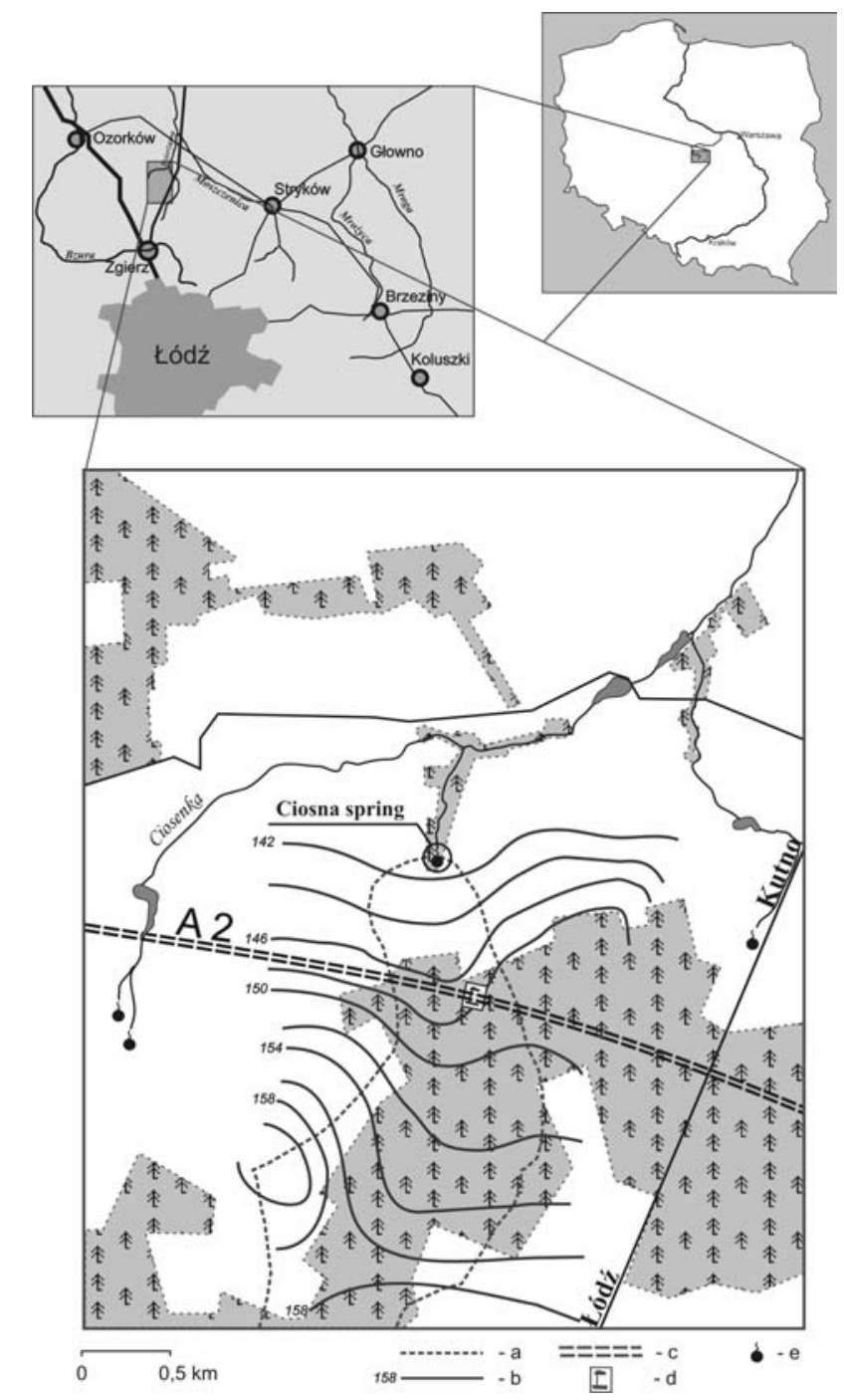




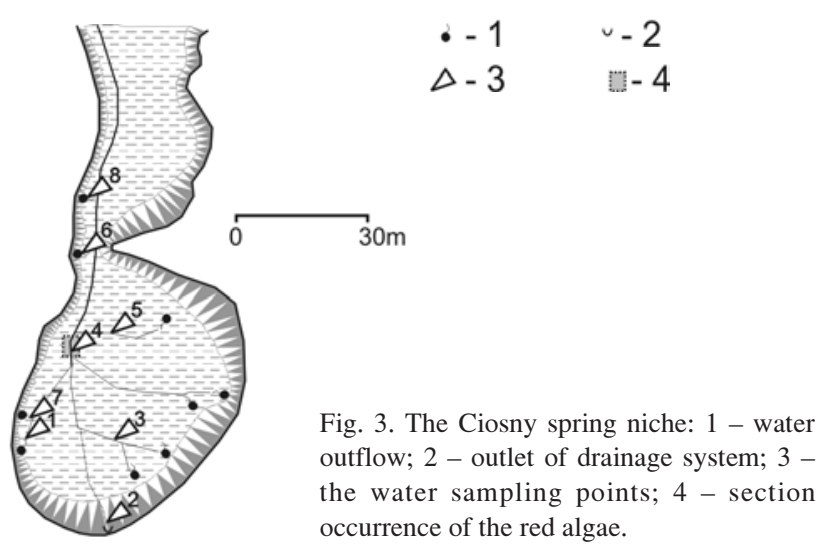

Topographic catchments of the Ciosny spring in its central and low part is developed by agriculture. All farms existing there have water supply systems and sewage is stored in cesspools. In the upper part of the catchment is a coniferous forest.

\section{MATERIAL AND METHODS}

The research has been done since 2003. Once per month identification of physicochemical properties of water (temperature, $\mathrm{pH}$ reaction, electrolytic conductivity, redox potential and dissolved oxygen) and measurements of spring yield took place. Once per quarter a chemical analysis of spring water samples in relation to main properties and elements (dry residue, oxidizability, $\mathrm{TH}$, silica, $\mathrm{Cl}^{-}, \mathrm{HCO}_{3}^{-}$, $\mathrm{SO}_{4}{ }^{2-}, \mathrm{Ca}^{2+}, \mathrm{Mg}^{2+}, \mathrm{Na}^{+}, \mathrm{K}^{+}, \mathrm{NO}_{3}{ }^{-}, \mathrm{NO}_{2}{ }^{-}, \mathrm{PO}_{4}{ }^{3-}, \mathrm{NH}_{4}{ }^{+}, \mathrm{Fe}^{2+}$, $\mathrm{Mn}^{2+}$ ) was performed. Selected heavy metals concentrations $\left(\mathrm{Cd}^{6+}, \mathrm{Cu}^{2+}, \mathrm{Ni}^{2+}, \mathrm{Pb}^{3+}, \mathrm{Zn}^{2+}, \mathrm{As}^{3+}\right.$ and $\left.\mathrm{Al}^{3+}\right)$ and organochloric pesticides were analyzed once in October 2004 (Witczak and Adamczyk 1995).

Lightness magnitude has been measured in the place of $H$. rivularis occurrence in a spring niche and in the uncovered place $3 \mathrm{~m}$ far from it. Lux meter type L-02 (SONOPAN) was used.

Since November 2003 observations of the occurrence of $H$. rivularis have been made. The surface of area settled by this red alga, dimensions of the stones and their surface covered by their thalli have been noted. The goal of the observations was to determine phenological diversity and hydrochemical parameters influence on the condition of $H$. rivularis thalli.

\section{RESULTS}

In the area where red algae have been discovered, water channels have a 2-2.5 meter width and maximum depth of $12-15 \mathrm{~cm}$. The mean velocity of the water flow is 0.137 $\mathrm{m}^{*} \mathrm{~s}^{-1}$, whereas minimal $0.06 \mathrm{~m}^{*} \mathrm{~s}^{-1}$ and maximal 0.295 $\mathrm{m} * \mathrm{~s}^{-1}$. The highest recorded velocity was $0.47 \mathrm{~m}^{*} \mathrm{~s}^{-1}$. In this range of water velocity in the channel bed, rock grains of diameter from 0.4 to $2.0 \mathrm{~mm}$ are unstable (Klimaszewski 1981).

TABLE 1. Physicochemical properties and chemical elements of the spring water in the Ciosny identified between $2003-2004$ in point no. 7 ( $\mathrm{n}=8$ ).

\begin{tabular}{|c|c|c|c|}
\hline Hydrochemical feature & Mean & Minimum & Maximum \\
\hline Temperature $\left[{ }^{\circ} \mathrm{C}\right]$ & 9.2 & 8.9 & 9.5 \\
\hline Colour of water $\left[\mathrm{mg} \mathrm{Pt}^{*} \mathrm{dm}^{-3}\right]$ & 4.4 & 3.0 & 5.0 \\
\hline Electrolytical conductivity $\left[\mu S^{*} \mathrm{~cm}^{-1}\right]$ & 288 & 270 & 307 \\
\hline $\mathrm{pH}$ reaction $[\mathrm{pH}]$ & 7.84 & 7.03 & 8.71 \\
\hline Redox potential [mV] & 217 & 181 & 246 \\
\hline Dry residue $\left[\mathrm{mg}^{*} \mathrm{dm}^{-3}\right]$ & 240.60 & 169.00 & 346.00 \\
\hline Total hardness $\left[\mathrm{mval}^{*} \mathrm{dm}^{-3}\right]$ & 2.72 & 1.90 & 3.38 \\
\hline Oxidizability $\left[\mathrm{mgO}_{2} * \mathrm{dm}^{-3}\right]$ & 1.85 & 1.55 & 2.43 \\
\hline $\mathrm{HCO}_{3}{ }^{-}\left[\mathrm{mg}^{*} \mathrm{dm}^{-3}\right]$ & 106.50 & 91.50 & 115.90 \\
\hline $\mathrm{Cl}^{-}\left[\mathrm{mg}^{*} \mathrm{dm}^{-3}\right]$ & 12.51 & 11.60 & 14.00 \\
\hline $\mathrm{SO}_{4}{ }^{2-}\left[\mathrm{mg}^{*} \mathrm{dm}^{-3}\right]$ & 41.00 & 23.60 & 64.40 \\
\hline $\mathrm{NO}_{3}{ }^{-}\left[\mathrm{mg}^{*} \mathrm{dm}^{-3}\right]$ & 22.40 & 15.90 & 29.00 \\
\hline $\mathrm{NO}_{2}^{-}\left[\mathrm{mg}^{*} \mathrm{dm}^{-3}\right]$ & 0.01 & 0.000 & 0.026 \\
\hline $\mathrm{Na}^{+}\left[\mathrm{mg}^{*} \mathrm{dm}^{-3}\right]$ & 5.17 & 4.80 & 5.50 \\
\hline $\mathrm{K}^{+}\left[\mathrm{mg}^{*} \mathrm{dm}^{-3}\right]$ & 1.15 & 0.80 & 2.20 \\
\hline $\mathrm{Ca}^{2+}\left[\mathrm{mg}^{*} \mathrm{dm}^{-3}\right]$ & 47.55 & 44.40 & 50.30 \\
\hline $\mathrm{Mg}^{2+}\left[\mathrm{mg}^{*} \mathrm{dm}^{-3}\right]$ & 4.82 & 4.50 & 5.30 \\
\hline $\mathrm{Fe}^{2+}\left[\mathrm{mg}^{*} \mathrm{dm}^{-3}\right]$ & 0.02 & 0.01 & 0.09 \\
\hline $\mathrm{Mn}^{2+}\left[\mathrm{mg}^{*} \mathrm{dm}^{-3}\right]$ & 0.002 & 0.001 & 0.002 \\
\hline $\mathrm{NH}_{4}^{+}\left[\mathrm{mg}^{*} \mathrm{dm}^{-3}\right]$ & 0.16 & 0.10 & 0.26 \\
\hline $\mathrm{SiO}_{2}\left[\mathrm{mg}^{*} \mathrm{dm}^{-3}\right]$ & 14.61 & 11.50 & 19.70 \\
\hline $\mathrm{O}_{2}\left[\mathrm{mg}^{*} \mathrm{dm}^{-3}\right]$ & 3.17 & 1.91 & 5.20 \\
\hline $\mathrm{O}_{2}[\%]$ & 28.38 & 17.30 & 46.10 \\
\hline $\mathrm{Al}^{3+}\left[\mu \mathrm{g}^{*} \mathrm{dm}^{-3}\right]$ & 14.4 & & \\
\hline $\mathrm{Cd}^{2+}\left[\mu \mathrm{g} * \mathrm{dm}^{-3}\right]$ & 0.05 & & \\
\hline $\mathrm{Cu}^{2+}\left[\mu \mathrm{g} * \mathrm{dm}^{-3}\right]$ & 4.27 & & \\
\hline
\end{tabular}



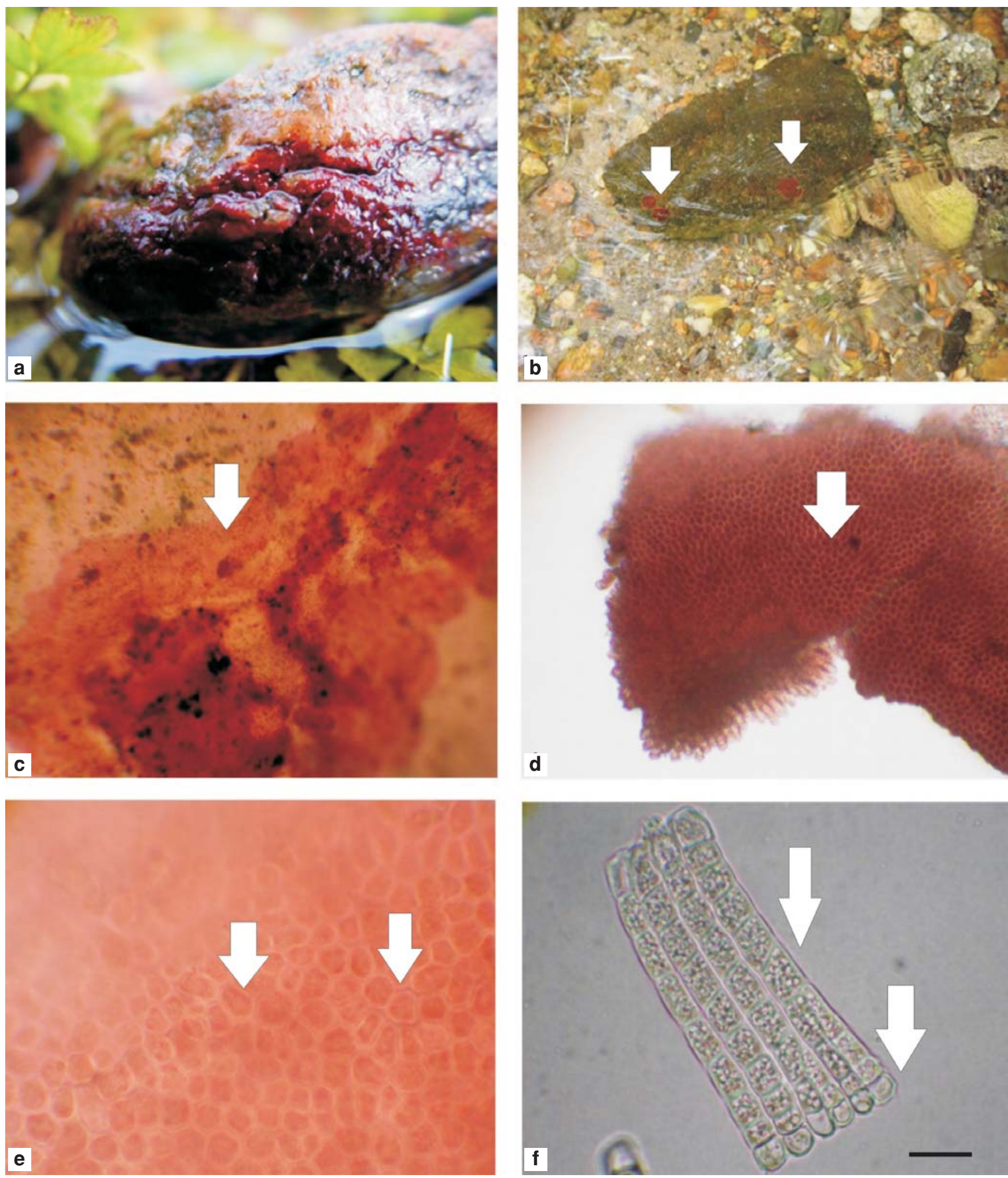

Fig. 4. a-f. Hildenbrandia rivularis: $\mathrm{a}, \mathrm{b}-$ thalli on the stone (macroscopic); $\mathrm{c}$ - thalli growing surface on the stone; $\mathrm{d}$ - part of thallus growing in different directions; $\mathrm{e}$ - thallus seen from the top; $\mathrm{f}-$ part of thalli in vertical section (Scale bar $=10 \mu \mathrm{m})$.

In the bottom of the Ciosny spring area there are stones coated with red color, shell-form thalli of $H$. rivularis (Fig. $4 \mathrm{a}, \mathrm{b})$. Distribution of the stones covered with red alga thalli is diverse, there are as many in the fast flow current as beyond it, but water always flows on them.

The size of the overgrown stones differs from a few $\mathrm{cm}$ diameters, flat around $1 \mathrm{~cm}$ thick to above $20 \mathrm{~cm}$ length and a few $\mathrm{cm}$ height. Thalli of this red algae grow over big stones on the current side and along the edge of the stone ac- cording to water flow (Fig. 4a), while small ones, form on their surface dots approximately $1 \mathrm{~cm}$ in diameter (Fig. 4b). Thalli of the $H$. rivularis were characterized with intensive red color and increased surface and number of settled stones in the period of time, from the end of May till October, while during winter their color changed to red brownish and single thalli disappeared on the stones in the shallow places. During the vegetation season, the occurrence place of $H$. $r$ vularis is overgrown with Berula erecta (Huds) Coville. 


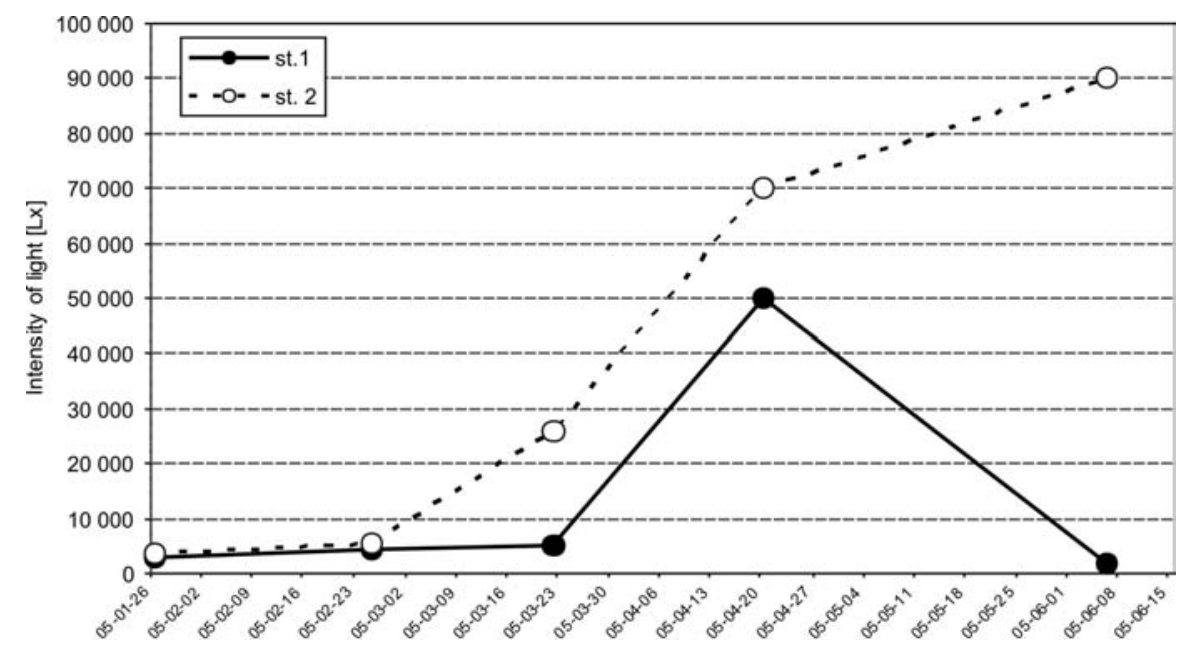

Fig. 5. Changes of light intensity recorded during first 2005 half-year observation on the red algae on station (st. 1) and expose part of niche - background (st. 2).
Thalli are growing in the peripheral part, radially in all directions, (Fig. 4c, d). The cells in the parallel view to the surface of thallus are irregular in shape and range from extended to polygonal (Fig. 4e). The central part of thallus is multilayered, built from $8-12$ cellular threads. The most superficial layer is dichotomously divided (Fig. 4f) and colourless. The breadth of cells measure approximately from 4 to $8 \mu \mathrm{m}$, and the length from 6 to $10 \mu \mathrm{m}$. The proportion of length to breadth of the cells in different parts of creating thalli threads are variable.

The light conditions of this red alga locality are similar to the exposure field (Fig. 5) as long as the alder trees are covered with leaves then changes. Sunlight available to all areas is reduced in the afternoon by the neighboring pine forest.

The spring water in Ciosny is fresh, low alkaline, soft and is of $\mathrm{HCO}_{3}-\mathrm{SO}_{4}$-Ca hydrochemical type. High changeability during hydrochemical researches represented $\mathrm{K}^{+}$, $\mathrm{SO}_{4}{ }^{2-}$, silica and dry residue, also $\mathrm{NO}_{3}{ }^{-}$and $\mathrm{PO}_{4}{ }^{3-}$ were raised. Physicochemical properties are presented in Table 1.

Hydrochemical analyses of individual outflows in area indicate a low but permanent differentiation (Fig. 6). It concerns such chemical elements, which act as pollution indexes (Fig. 6). Values which were recorded in niche outflow (point 4 - see Fig. 3) represented mean conditions of all the niche. Interestingly, high concentration of $\mathrm{NO}_{3}{ }^{-}$in water outflow in upper part of the niche (point 1 and 7) was noted.
In this part of the niche the water from ploughland draining system periodically appears, characterized by high concentration of $\mathrm{NO}_{3}^{-}\left(\max .148 .7 \mathrm{mg}^{*} \mathrm{dm}^{3}\right)$. However, as the result of water outflow in upper part of the niche, their concentration gradually decreases. Dissolved oxygen accompanies with mentioned phenomenon respectively in point 1 : $36-40 \%$ and in point $7: 17-46 \%$ while in point $4: 70-83 \%$.

Hydrochemical differentiation between water outflows from both sides of niche, eastern and western was also noted (Table 2). Farms and ploughlands are located in eastern part of the drainage basin, while forests and ploughlands in the western one. $\mathrm{NH}_{4}{ }^{+}$and $\mathrm{PO}_{4}{ }^{3-}$ were noted in all analyzed outflows on a similar level.

\section{CONCLUSIONS}

The noted stand of Hildenbrandia rivularis is the first in central Poland. This allows to verify the suggestion about it's occurrence restricted to the mountain and Lake District areas (Markowski 1980). Appearance of $H$. rivularis on the Polish Lowland was noted to date most frequently in the range of the last Vistulian glaciations in rivers and single stands in stagnant waters (Fig. 1). Substantiated occurrence of this red algae in the Ciosny spring niche, points out to the next type of settlement, in which $H$. rivularis occurs. a

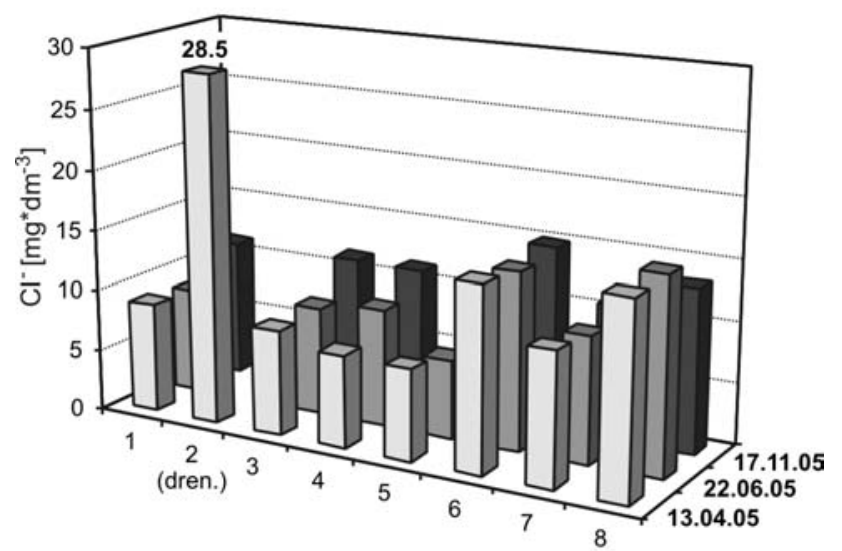

b

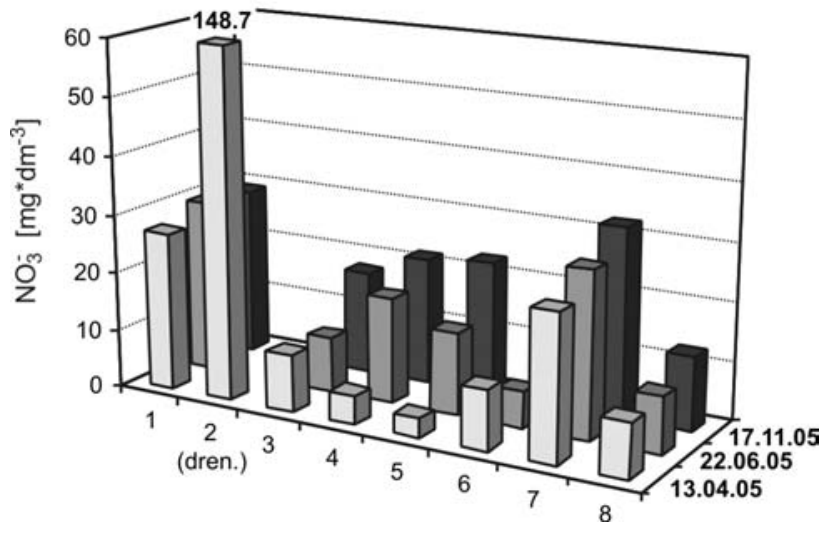

Fig. 6 a-b. Differentiation of concentration selected chemical elements at water points' sampling in the Ciosny spring: a - chlorides; b - nitrates. 
TABLE 2. Mean concentrations of analyzed chemical elements of waters, which outflow in the Ciosny spring niche.

\begin{tabular}{|c|c|c|}
\hline Chemical element and date of analysis & Western part of niche $\left[\mathrm{mg}^{*} \mathrm{dm}^{-3}\right]$ & Eastern part of niche $\left[\mathrm{mg}^{*} \mathrm{dm}^{-3}\right]$ \\
\hline $\mathrm{SO}_{4}^{2-} /$ VI. $2004 \mathrm{r}$. & 46.4 & 36.1 \\
\hline $\mathrm{SO}_{4}^{2-} / \mathrm{IV} .2005 \mathrm{r}$ & 43.8 & 33.9 \\
\hline $\mathrm{Cl}^{-} /$VI. 2004 r. & 12.3 & 7.7 \\
\hline $\mathrm{Cl}^{-} / \mathrm{IV} .2005 \mathrm{r}$. & 12.7 & 8.1 \\
\hline $\mathrm{NO}_{3}^{-} /$VI. 2004 r. & 19.7 & 13.4 \\
\hline $\mathrm{NO}_{3}^{-} /$IV. $2005 \mathrm{r}$. & 17.8 & 6.5 \\
\hline $\mathrm{NH}_{4}^{+} /$VI. 2004 r. & 0.23 & 0.22 \\
\hline $\mathrm{NH}_{4}^{+} /$IV. 2005 r. & 0.48 & 0.34 \\
\hline $\mathrm{PO}_{4}^{3-}$ / VI. 2004 r. & 0.34 & 0.29 \\
\hline $\mathrm{PO}_{4}^{3-} / \mathrm{IV} .2005 \mathrm{r}$ & 0.43 & 0.42 \\
\hline
\end{tabular}

Light conditions where $H$. rivularis occurs are similar during summer and winter. Amount of light during the wintertime is connected to the day-light time. Whereas, during the summertime it is connected to the vascular plant, growing in the spring niche and in their surrounding.

Until now in Poland only Starmach $(1969,1982)$ studied the physical and chemical conditions in the place of $\mathrm{H}$. rivularis occurrence, such as $\mathrm{pH}$ ranging 6-8, alkaline 1-1.6 mval, water temperature $0-15^{\circ} \mathrm{C}$ and discharge $0.3 \mathrm{~m}^{3 *} \mathrm{~s}^{-1}$. Markowski (1980) has announced, that this alga occurred in water flowing $25-100 \mathrm{~cm}^{*} \mathrm{~s}^{-1}$.

The ecological classification of $H$. rivularis in relation to trophic state, $\mathrm{pH}$, saprobity, water hardness and ecological type of waters is as follow: eutrophic, alkaline waters, xeno- to oligosaprobic, hard waters (Eloranta and Kwandrans 2004).

Gutowski et al. (2004) has classified H. rivularis to a category of less sensitive species, more widely distributed, indicator of good water quality conditions. This taxa was noted in German rivers with water hardness (0.2-4.4 $\mathrm{mmol} / \mathrm{l})$, conductivity $(56-2335 \mu \mathrm{S} / \mathrm{cm}), \mathrm{pH}(7-8.3)$, and tolerated higher amounts of $\mathrm{NO}_{3}-\mathrm{N}$ (to $12.5 \mathrm{mg} / \mathrm{l}$ ), but more sensitive to $\mathrm{P}$ enrichment (below TP $0.5 \mathrm{mg} / \mathrm{l}$ ).

The water in the Ciosny spring niche is soft and lightly alkaline. It's temperature does not exceed $10^{\circ} \mathrm{C}$, has characteristic small annual amplitude and velocity oscillating from 6 to $29.5 \mathrm{~cm} / \mathrm{s}$ (Table 1 ).

Based on performed studies, a wide range of hydrochemical parameters creating conditions favorable to $H$. rivularis development has been determined. Classification of the Ciosny spring water quality upon 31 properties indicated class Ib (high quality). Nitrate nitrogen plays a major role in this result. Effluent differentiation of water chemical composition in different parts of the spring niche points out, that this spring is situated in the zone of influence of the local sources of pollutions (neighboring farmsteads).

The localization of storage-infiltration reservoir of highway $\mathrm{A} 2$ in close distance to the Ciosny spring creates a very important threat to the water quality (Fig. 2). The local topographic and hydrogeology conditions are favorable for rising wastes possibly ions, such as: $\mathrm{Cl}^{-}, \mathrm{Mg}^{2+}, \mathrm{Ca}^{2+}, \mathrm{Na}^{+}$, $\mathrm{PO}_{4}{ }^{3-}$ and $\mathrm{Cr}, \mathrm{Pb}$ to the niche, in the direction of groundwater flow (Kleczkowski 1984).

\section{ACKNOWLEDGMENTS}

The authors are very grateful to Prof. R. Gołdyn for his critical consultation of this manuscript. This research was supported by the State Committee for Scientific Research, grant no. 3P04G 05723.

\section{LITERATURE CITED}

BOHR R. 1968. The first lacustrine locality of Hildenbrandia rivularis (Liebm.) I. Ag. in Poland found in Jeziorak Lake. Zeszyty Nauk. UMK w Toruniu. Nauki matematyczno-przyrodnicze. 20 (4): 27-30.

CHUDYBA H., POLAKOWSKI B. 1977. W sprawie utworzenia rezerwatu przyrody na rzece Krutyni. Chrońmy Przyrodę Ojczystą 33 (5-6): 93-96. (in Polish)

DĄMBSKA I. 1961. Hildenbrandia rivularis (Liebm.) Breb. w okolicy Międzychodu. (Hildenbrandia rivularis (Liebm.) Breb. in the environments of Międzychód). Bad. Fizjogr. Pol. Zach. 8: 235. (in Polish with English summary)

ELORANTA P., KWADRANS J. 2004. Indicator value of freshwater red algae in running waters for water quality assessment. Oceanological and Hydrobiological Studies 33 (1): 47-54.

GOŁDYN R. 1985. Jeziorne stanowisko Hildenbrandia rivularis (Liebm.) I. Ag. w pobliżu Międzychodu. Bad. Fizjogr. Pol. Zach. 36, Seria B: 185-188. (in Polish with English summary)

GUTOWSKI A., FOERSTER J., SCHAUMBURG J. 2004. The use of benthic algae, excluding diatoms and Charales, for the assessment of the ecological status of running fresh waters: a case history from germany. Oceanological and Hydrobiological Studies 33 (2): 3-15.

KEPCZYŃSKI K. 1963. Stanowiska Hildenbrandia rivularis (Liebm.) I. Ag. Na Wysoczyźnie Dobrzyńskiej. (Die Standorte von Hildenbrandia rivularis (Liebm.) I. Ag. auf dem DobrzyńDiluvialplateau). Fragm. Flor. Geobot. 9 (4): 499-501. (in Polish with German summary)

KEPCZYŃSKI K. 1972. Nowe stanowiska Hildenbrandia rivularis (Liebm.) I. Ag. w rzece Drwęcy i jej dopływach (Neue Standorte von Hildenbrandia rivularis (Liebm.) I. Ag. in dem Drwęca-Fluss und In seinen Nebenflüssen). Zeszyty Nauk. UMK w Toruniu. Nauki matematyczno-przyrodnicze. 30, Biol. 15: 73-75. (in Polish with German summary)

KĘPCZYŃSKI K., PEPLIŃSKA B. 1995. Nowe stanowiska chronionych i rzadziej spotykanych gatunków roślin w okolicach miejscowości Rogoźno Wielkopolskie. (Neue Standorte der geschützten und raren Pflanzenarten der Umgebung von Rogoźno Wielkopolskie (Teil I) Acta Univerisitatis Nicolai Copernici, Biologia 48: 177-183. (in Polish with German summary) 
KLECZKOWSKI A.S. (ed.). 1984. Ochrona wód podziemnych. Wyd. Geolog., Warszawa: 1-328. (in Polish)

KLIMASZEWSKI M. 1981. Geomorfologia ogólna. PWN, Warszawa: 1-1063. (in Polish)

KRAWIEC F. 1935. Ciekawe krasnorosty Hildenbrandia rivularis (Liebm.) I. Ag. i Thorea ramosissima Bory w Wielkopolsce. (Interessante Süsswaserrotalgen Hildenbrandia rivularis (Liebm.) I. Ag. und Thorea ramosissima Bory in Grosspolen). Acta Soc. Bot. Pol. 12 (3): 299-300. (in Polish with German summary)

KRÓL S. 1987. Nowe stanowisko Hildenbrandia rivularis (Liebm.) I. Ag. w Krainie Wielkopolsko-Kujawskiej w rzece Pliszce. Bad. Fizjogr. Pol. Zach. 38, Seria B: 181-182. (in Polish with English summary)

LISOWSKI S., SZAFRAŃSKI F., TOBOLSKI K. 1971. Stanowisko Hildenbrandia rivularis (Liebm.) I. Ag. w rzece Wda (pow. Chojnicki). (A new locality of Hildenbrandia rivularis (Liebm.) I. Ag. in the river Wda (District Chojnice). Bad. Fizjogr. Pol. Zach. 24, Seria B: 273-274. (in Polish with English summary)

MAKSYMIUK Z., MELA S. 1995. Źródła Polski Środkowej. Acta Univ. Lodz. Folia Geograph. 20: 109-119. (in Polish with English summary)

MARKOWSKI R. 1980. Hildenbrandia rivularis (Liebm.) I. Ag. na pobrzeżu i Pojezierzu Kaszubskim (Hildenbrandia rivularis (Liebm.) I. Ag. (In the Kashubian Coast and Kashubian Lake Region). Zeszyty Nauk. Wydz. Biol. Nauk o Ziemi Uniw. Gdańskiego. Biologia. 2: 91-99. (in Polish with English summary)

MONIEWSKI P. 2004. Źródła okolic Łodzi. Acta Geograph. Lodz. 87. ŁTN, Łódź. (in Polish with English summary).

PAZDRO Z., KOZERSKI B. 1990. Hydrogeologia ogólna. Wyd. Geolog. Warszawa: 1-624. (in Polish)

SIEMIŃSKA J. 1962. Dalsze stanowiska Hildenbrandia rivularis na Pomorzu Zachodnim (New localities of Hildenbrandia rivularis in Western Pomerania). Frag. Flor. Geobot. 8 (1): 89. (in Polish with English summary)

SIEMIŃSKA J. 1992. Red list of threatened algae in Poland. In: K. Zarzycki, W. Wojewoda, Z. Heinrich (eds). List of threatened plants In Poland (2nd ed.) Polish Academy of Sciences, W. Szafer Institute of Botany, Cracow: 7-19.

STARMACH K. 1952. O rozmnażaniu się krasnorostu Hildenbrandia rivularis (Liebm.) I. Ag. (The reproduction of the fresh water Rhodophyceac Hildenbrandia rivularis (Liebm.) I. Ag.) Acta Soc. Bot. Pol. 21 (3): 447-474. (in Polish with English summary)
STARMACH K. 1969a. Hildenbrandia rivularis (Liebm.) I. Ag., Chamaesiphon fuscoviolaceus n. sp. i glony towarzyszące w potoku Lubogoszcz w Beskidzie Wyspowym (Hildenbrandia rivularis (Liebm.) I. Ag. and Chamaesiphon fuscoviolaceus $\mathrm{n}$. sp., and accompanying algae in the stream Lubogoszcz in the Beskid Wyspowy (Polish Western Carpathians). Fragm. Flor. Geobot. 15 (4): 487-501. (in Polish with English summary)

STARMACH K. 1969b. Growth of thalli and reproduction of the red alga Hildenbrandia rivularis (Liebm.) I. Ag. Acta Soc. Bot. Pol. 38 (3): 523-533.

STARMACH K. 1982. Red algae in the Kryniczanka stream. Fragm. Flor. Geobot. 28 (2): 257-293.

STĘPCZAK K., MUSIAŁ J. 1984. Hildenbrandia rivularis (Liebm.) I. Ag. na terenie Pszczewskiego Parku Krajobrazowego w województwie gorzowskim. Bad. Fizjogr. Pol. Zach. 35, Seria B: 167-168. (in Polish with English summary)

SZAFRAŃSKI F. 1960. Stanowisko Hildenbrandia rivularis (Liebm.) I. Ag. w rzece Obrze koło Starego Dworku (pow. Skwierzyna). (Hildenbrandia rivularis (Liebm.) I. Ag. found in the river Obra by Stary Dworek (District Skwierzyna). Bad. Fizjogr. Pol. Zach. 6: 283-284. (in Polish with English summary)

WITCZAK S., ADAMCZYK A. 1995. Katalog wybranych fizycznych i chemicznych wskaźników zanieczyszczeń wód podziemnych i metod ich oznaczania. T. I i II. Państwowa Inspekcja Ochrony Środowiska, Warszawa. (in Polish)

ZIUŁKIEWICZ M. 2001. Azotany w wodach źródlanych Parku Krajobrazowego Wzniesień Łódzkich. Przyroda Polski Środkowej 4: 16-18. (in Polish)

ZIUŁKIEWICZ M. 2005a. Przyczyny zmienności chemizmu źródeł strefy krawędziowej Wzniesień Łódzkich. Współczesne Problemy Hydrogeologii XII, Toruń: 743-747. (in Polish)

ZIUŁKIEWICZ M. 2005B. Chlorki jako wskaźnik zanieczyszczenia wód podziemnych na obszarze Łodzi. Mat. Konferencji: Geologia regionu łódzkiego - przeszłość dla przyszłości. Wyd. UŁ, Łódź (in press). (in Polish with English summary)

ŻELAZNA-WIECZOREK J., ZIUŁKIEWICZ M. 2004. Algae communities in springs of Łódź Hills scarp with diversified hydrochemical conditions. Teka Komisji Ochrony i Kształtowania Środowiska Przyrodniczego, PAN, Lublin I: 322-330.

ŻUKOWSKI W. 1963. Nowo odkryte stanowiska Hildenbrandia rivularis (Liebm.) I. Ag. na Pomorzu Zachodnim. Bad. Fizjogr. Pol. Zach. 12: 357. (in Polish) 